\title{
The Effectiveness of Iron Tablets Consumption in Pregnant Women to Ferritin Levels in Ilir Timur I Palembang
}

\author{
$1^{\text {st }}$ Romlah \\ Midwifery Program, Faculty of Health Sciences \\ University of Chatolic Musi Charitas \\ Palembang, Indonesia \\ ireneromlah@ukmc.ac.id
}

\author{
$2^{\text {nd }}$ Anjelina Puspita Sari \\ Midwifery Program, Faculty of Health Sciences \\ University of Chatolic Musi Charitas \\ Palembang, Indonesia \\ angelinaps88@gmail.com
}

Corresponding author: angelinaps88@gmail.com

\begin{abstract}
Since pregnant women who lack iron can cause iron deficiency anemia, this incidence must be prevented seriously. Based on the WHO data, the total population of anemia worldwide was $83.2 \%$ of 114 countries, while for Southeast Asia, it was $97.8 \%$. Anemia in pregnant women in Indonesia ranked fourth with Thailand at 30\%. This study aimed to determine the effectiveness of consumption of iron tablets in pregnant women against serum ferritin levels. This observational analytic study used the pretest and posttest control group design. Sixteen pregnant women with the inclusion criteria: Second trimester pregnant women, a single pregnant. Fe tablets given to respondents were in accordance with government programs, and taking blood serum for ferritin levels collaboration with public health center ilirtimur I Palembang. The measurement of serum ferritin levels used Elisa in the Central Laboratory of Health Laboratory of Palembang. Data was analyzed by paired T-Test. The test results showed that the mean ferritin level in pregnant women after consuming 30 iron tablets for 30 days was higher $(21.68 \mathrm{ng} / \mathrm{ml} \pm 10.61)$ than those who had not consumed the tablets $(17.29 \mathrm{ng} / \mathrm{ml} \pm$ 9.90). Result showed there were significant differences in ferritin levels in pregnant women before and after (30 tablets for 30 days) consuming iron tablets $(p=0.014)$. It is then recommended that the administration of iron tablets and support for pregnant women to comply with the consumption of iron tablets must be enhanced in accordance with the rules set by the government.
\end{abstract}

Keywords: Pregnancy, Iron, and Ferritin.

\section{INTRODUCTION}

Anemia is a condition where the level of hemoglobin $(\mathrm{Hb})$ in the blood is less than $11 \mathrm{~g} / \mathrm{dL}$ [1]. When it occurs in pregnancy, the administration of iron tablets is set for its service standards. As recommended, pregnant women should consume 1 tablet daily or 90 tablets during pregnancy [2].

Iron is a micro mineral that is most abundant in the human body. It is a part of hemoglobin that functions as a means of transporting oxygen to body tissues. During antenatal period, most of the iron is used during the second half of pregnancy; therefore, the need for iron becomes greater after mid-pregnancy. To address the upcoming problem, there is a need for iron supplementation, to avoid the fall of the concentration of hemoglobin and hematocrit (Ht) significantly as blood volume increases [3].

Pregnant women may be at risk of iron deficiency anemia. Its examination can be seen from the low levels of serum ferritin and iron [4]. Ferritin is currently considered an important indicator in determining iron status [5]. Darwanty in her study stated that the amount of $\mathrm{Fe}$ consumed by pregnant women during pregnancy had to do with the incidence of anemia in pregnancy[6].

Iron deficiency is a major contributor to anemia by $50 \%$ when compared to anemia caused by other factors. In 2013, maternal and neonatal deaths in developing countries reached around 3 million with an estimated 90,000 deaths caused by iron deficiency anemia [7]. Based on the WHO data, the total population of anemia worldwide was $83.2 \%$ of 114 countries, while for Southeast Asia, it was $97.8 \%$. Anemia in pregnant women in Indonesia ranked fourth with Thailand at $30 \%$. This figure was higher that that 
of Malaysia and Singapore, at $27 \%$ and $28 \%$, respectively[8].

The government of Indonesia has made an effort to overcome anemia in pregnancy by giving $90 \mathrm{Fe}$ tablets to pregnant women during their pregnancy period with the aim of suppressing the anemia rate; however, the incidence of anemia in Indonesia is still high. Data from the Basic Health Research (RISKESDAS) showed the prevalence of anemia in pregnancy remained $37.1 \%$. This shows that iron deficiency anemia is still a public health problem [9].

Data from the Palembang City Health Office showed an increasing trend of anemia incidence. The coverage of Fe1 (30 tablets) for Palembang in 2017 was $99.12 \%$ and Fe-3 (90 tablets) was $97.23 \%$. The coverage of Fe1 was highest in Plaju Sub-district and lowest in Ilir Timur I Sub-district[10]. Based on these descriptions, a study concerning anemia in pregnancy and $\mathrm{Fe}$ consumption in relation to serum ferritin level needed to be done.

\section{METHODS}

This observational analytic study used a pretest and posttest control group design. This study was located in Ilir Timur I Palembang, conducted in June-December 2019. The sample in this study was a total sampling of 16 respondents and in accordance with the inclusion criteria: Second trimester pregnant women (13-27 weeks gestational age) who were willing to become respondents and take iron tablets for 30 days, a single pregnant woman obtained from the results of a physical examination, primigravida (first child) or multigravida (second to fourth child). The exclusion criteria in this study were pregnancy with complications, those who forgot to take 1 or more iron tablets during the study, those who were sick while they were doing the study, and those who could not be contacted during the study.

Data collected in this study were primary data obtained by observing pregnant women in the form of biodata, and taking blood serum for ferritin levels (pretest and posttest). The measurement of serum ferritin levels used Elisa Reader method in the Central Laboratory of Health Laboratory of Palembang.

Data analysis was carried out in stages which included univariate analysis to find out the frequency distribution of each variable presented in the form of frequencies and percentages. Bivariate analysis used a normality test first. The results obtained normal data distribution, followed by statistical tests using paired ttest to see differences in ferritin levels before and after taking iron tablets.

\section{RESULTS}

Of the 16 respondents, the majority had graduated from high school (8 people/50\%), were multigravida (10 people/62.5\%), and were aged $20-35$ years (15 people/93.8\%) (Table 1).

Table 1. Univariate Analysis Results

\begin{tabular}{lcc}
\hline Characteristics & n $(\%)$ & Total n (\%) \\
\hline Education & & \\
Elementary school & $0(0)$ & \\
Junior High school & $1(6.3)$ & $16(100)$ \\
Senior High school & $8(50)$ & \\
University & $7(43.8)$ & \\
\hline Gravida & & \\
Primigravida & $6(37.5)$ & $16(100)$ \\
Multigravida & $10(62.5)$ & \\
\hline Age & & \\
$20-35$ & $15(93.8)$ & $16(100)$ \\
$<20$ and $>35$ & $1(6.3)$ & \\
\hline
\end{tabular}

The average ferritin level in pregnant women after consuming 30 iron tablets was higher than that in pregnant women who did not take iron tablets (Table $2)$. Analysis showed that there were differences in ferritin levels in pregnant women before and after (30 tablets) consuming iron tablets with a $\mathrm{p}$ value of 0.014 .

Table 2. Effectiveness of Iron Tablet Consumption in Pregnant Women to Ferritin Levels

\begin{tabular}{ccccc}
\hline $\begin{array}{c}\text { Number of Fe } \\
\text { Tablets }\end{array}$ & $\begin{array}{c}\text { Feritin Level } \\
(\mathbf{n g} / \mathbf{m l}) \\
\text { Means } \pm \text { SD }\end{array}$ & $\mathbf{n}$ & $\%$ & $\boldsymbol{P}$ \\
\hline 0 Tablet & $17.29 \pm 9.90$ & 16 & 100 & 0.014 \\
30 Tablet & $21.68 \pm 10.61$ & 16 & 100 & \\
\hline
\end{tabular}

\section{DISCUSSION}

Statistical analysis showed that the average ferritin level in pregnant women after consuming 30 iron tablets was higher than that in pregnant women who had not consumed. Statistical analysis showed that there were differences in ferritin levels in pregnant women before and after consuming iron tablets with a $\mathrm{p}$ value of 0.014 .

Pregnant women in the government program are required to consume a number of 90 iron tablets during pregnancy [2]. Absorption of iron tablets is much influenced by various factors, including diseases that accompany the women during pregnancy and also the consumption of Vitamin $\mathrm{C}$ which can help the body absorb iron from food. Some foods reduce the ability to absorb iron such as tea, coffee, and foods containing calcium and other dairy products [4]. Absorption of 
iron occurs in duodenum. When absorption takes place, there will be an increase in iron in the blood, which in turn will increase ferritin in the blood [3].

Ferritin is a protein that binds with iron in the intracellular and extracellular compartments [5]. Level of ferritin is defined low as a serum ferritin level of less than $14 \mathrm{ng} / \mathrm{ml}$ and normal of 14-150 ng/ml [4]. Low blood ferritin status confirms that the body does not have enough iron [11]. Most iron is used during the second half of pregnancy so the need for iron becomes greater after mid-pregnancy. Iron with this amount is usually not available from iron stores, therefore iron needs will not be met without iron supplementation [3].

Pregnant women will develop physiological anemia starting in the second trimester. Physiological anemia is a term often used to describe the decrease in hemoglobin concentration that occurs during normal pregnancy. This happens because the expansion of plasma volume is greater than the increase in the mass of red blood cells which is often called hemodilution [4]. During normal pregnancy, there is an increase in plasma volume by $30-50 \%$ and an increase in the mass of red blood cells by $20-30 \%$ where this causes a decrease in $\mathrm{Hb}$ concentration [12].

Pregnant women need about $1000 \mathrm{mg}$ of iron during pregnancy, $500 \mathrm{mg}$ for increasing red blood cells (HR), $300 \mathrm{mg}$ for fetal, placental and uterine development, and $200 \mathrm{mg}$ for compensating for unconscious loss through the skin, feces, and urine [13]. However, pregnant women with high iron concentrations should limit Fe tablets [14]. Excessive iron deposits in tissues can cause serious damage to organs (hemochromatosis), specifically the heart, liver and endocrine organs [4].

A good balanced diet is very important to ensure pregnant women receive enough iron. The most absorbable iron comes from red meat, fish and poultry. However, there are vegetarian choices of green leafy vegetables like spinach. The most common side effects of consuming iron tablets are nausea, bloating, and constipation. The response to treatment after 2-4 weeks is that pregnant women will undergo a blood test to check whether the iron tablets are working. If there are significant changes, pregnant women continue to consume the tablets for another 3 months, to help increase iron stores in the body [15].

Another study measured plasma ferritin and dissolved transferrin receptors. Lack of iron supplementation is associated with an increase in moderate and severe iron deficiency, due to the increased need for iron during pregnancy; thus, every pregnant woman should get additional iron supplements, and this can be used as a strategy to prevent anemia [16]. Iron Deficiency and iron deficiency anemia there is relationship with fetal development, and early childhood parameters [17]. Other research stated that there is a significant relationship between serum ferritin and maternal $\mathrm{Hb}$ with pregnancy outcomes such as newborn weight, and premature birth [18].

This study is also in line with a study conducted by Falahi, et al who stated that iron supplementation during pregnancy in pregnant women who are not anemic but have low ferritin levels can be useful for the prevention of iron deficiency anemia [19]. This study is also in line with Dalal's study that the average ferritin levels increased before and after consumption of iron tablets [20]. In addition, serum ferritin levels were the lowest in pregnant women with severe anemia [21].

Other study stated that there was a correlation between iron intake in children 2-5 years with ferritin. It can be seen from the regression analysis that the contribution of Fe intake in increasing ferritin levels was $1,747 \mu \mathrm{g} / \mathrm{L}$. Ferritin is a reliable parameter in determining Fe status [22]. The administration or supplementation of $\mathrm{Fe}$ capsules to athletes also significantly influences changes in serum ferritin levels during menstruation, which is to maintain it within normal limits, so that the athlete's condition can continue training without interfering with his performance [23]

\section{CONCLUSION}

There are differences in ferritin levels in pregnant women before and after consuming iron tablets. Increased serum ferritin levels indicate an increase in body iron reserves. Pregnant women should be exposed with education and information the importance of consuming Fe tablets.

\section{ACKNOWLEDGMENT}

This acknowledgment is given to University of Catholic MusiCharitas especially Faculty of Health Science for funding the publication as proceeding article of oral presentation.

\section{REFERENCES}

[1] Organization Wh. Serum Ferritin Concentrations For The Assaament Of Iron Status And Iron Deficiency In Populations. 2011.

[2] Ri Kk. Profil Kesehatan Indonesia 2016. 2017.

[3] Sari Ap. Konsumsi Tablet Besi Terhadap Kadar Hemoglobin Ibu Hamil Trimester Dua The Effect Of Iron Consumption With Hemoglobin Level In Peneliti Tertarik Berdasarkan Uraian Diatas Untuk Mengadakan Penelitian 
Tentang " Tablet Fe Terhadap Kadar Hemoglobin ". Tujuan 2020;15:45-51. Https://Doi.Org/10.36086/Jpp.V15i1.466.

[4] Hoffbrand A V. Kapita Selekta Hematologi Edisi 6. 2013.

[5] Knovich Ma, Storey Ja, Coffman Lg, Torti S V., Torti Fm. Ferritin For The Clinician. Blood Rev 2009;23:95-104. Https://Doi.Org/10.1016/J.Blre.2008.08.001.

[6] Darwanty J. Hubungan Konsumsi Fe Terhadap Kejadian Anemia Pada Ibu Hamil Di Kabupaten Karawang Tahun 2014 Relationship Of Fe Consumption To Anemia In Pregnant Women In Kabupaten Karawang Year 2014 Jundra Darwanty Prodi Kebidanan Karawang, Poltekkes Kemenkes Bandung. J Kebidanan 2018;7:14-22.

[7] Organization Wh. The Global Prevalence Of Anemia In 2011. 2015 .

[8] Organization Wh. Global Nutrition Targets 2025. N.D.

[9] Ri Kk. Riskesdas 2013 Badan Penelitian Dan Pengembangan Kesehatan Kemenkes Ri. 2011.

[10] Dinas Kesehatan Kota Palembang. Profil Kesehatan Tahun 2017. Palembang; 2018.

[11] Brannon Pm, Taylor Cl. Iron Supplementation During Pregnancy And Infancy: Uncertainties And Implications For Research And Policy. Nutrients 2017;9:1-17. Https://Doi.Org/10.3390/Nu9121327.

[12] Fisher Al, Nemeth E. Iron Homeostasis During Pregnancy. Am J Clin Nutr 2017:106:1567s-1574s. Https://Doi.Org/10.3945/Ajcn.117.155812.

[13] Sharma Jb, Shankar M. Anemia In Pregnancy . Prevalence Of Anemia In. Indian J Med Res 2010;23:253-60.

[14] Alizadeh L, Salehi L. Is Routine Iron Supplementation Necessary In Pregnant Women With High Hemoglobin? Iran Red Crescent Med J 2016;18:1-5. Https://Doi.Org/10.5812/Ircmj.22761.

[15] Sari Ap. Konsumsi Tablet Fe Terhadap Kadar Hemoglobin Ibu Hamil Trimester Dua The Effect Of Iron Consumption With Hemoglobin Level In Second Trimester Pregnant Women Peneliti Tertarik Berdasarkan Uraian Diatas Untuk Mengadakan Penelitian Tentang " Tablet Fe Terhad 2020;15:45-51

[16] S.L. L, L.M. L, S.-Y. C, P.T. T, Y.L. C, P.L. Q, Et Al. Iron Status And Risk Factors Of Iron Deficiency Among Pregnant Women In Singapore: A Cross-Sectional Study. Bmc Public Health 2019;19:397.

[17] Means Rt. Iron Deficiency And Iron Deficiency Anemia: Implications And Impact In Pregnancy, Fetal Development, And Early Childhood Parameters. Nutrients 2020;12. Https://Doi.Org/10.3390/Nu12020447.

[18] Srour Ma, Aqel Ss, Srour Km, Younis Kr, Samarah F. Prevalence Of Anemia And Iron Deficiency Among Palestinian Pregnant Women And Its Association With Pregnancy Outcome. Anemia 2018;2018. Https://Doi.Org/10.1155/2018/9135625.

[19] Falahi E, Akbari S, Ebrahimzade F, Gargari Bp. Impact Of Prophylactic Iron Supplementation In Healthy Pregnant Women On Maternal Iron Status And Birth Outcome. Food $\begin{array}{lll}\text { Nutr } & \text { Bull 2011;32:213-7. }\end{array}$ Https://Doi.Org/10.1177/156482651103200305.

[20] Al Ra, Unlubilgin E, Kandemir O, Yalvac S, Cakir L, Haberal A. Intravenous Versus Oral Iron For Treatment Of Anemia In Pregnancy: A Randomized Trial. Obstet Gynecol 2005;106:1335-40. Https://Doi.Org/10.1097/01.Aog.0000185260.82466.B4.

[21] Sharma Jb, Bumma Sd, Saxena R, Kumar S, Roy Kk, Singh N, Et Al. Cross Sectional, Comparative Study Of Serum Erythropoietin, Transferrin Receptor, Ferritin Levels And Other Hematological Indices In Normal Pregnancies And Iron Deficiency Anemia During Pregnancy. Eur J Obstet Gynecol Reprod Biol 2016;203:99-103.

Https://Doi.Org/10.1016/J.Ejogrb.2016.05.022.
[22] Sunarti ., Nugrohowati Ak. Korelasi Status Gizi, Asupan Zat Besi Dengan Kadar Feritin Pada Anak Usia 2-5 Tahun Di Kelurahan Semanggi Surakarta. J Kesehat Masy (Journal Public Heal 2014;8:11-8. Https://Doi.Org/10.12928/Kesmas.V8i1.1037.

[23] Taiyeb A, Hammado N, Nawir N. Pengaruh Suplementasi Zat Besi (Fe) Terhadap Kadar Ferritin Darah Atlet Wanita Saat Menstruasi,. J Bionature 2012; Vol.13 No.1. 